\title{
U.S. science parks: the diffusion of an innovation and its effects on the academic missions of universities
}

\author{
Albert N. Link ${ }^{\mathrm{a}}$, John T. Scott ${ }^{\mathrm{b}, *}$ \\ a Department of Economics, University of North Carolina at Greensboro, Greensboro, NC 27402, \\ USA \\ ${ }^{\mathrm{b}}$ Department of Economics, Dartmouth College, Hanover, NH 03755, USA
}

\begin{abstract}
The paper is an exploratory study of science parks in the United States. It models the history of science parks as the diffusion of an innovation that was adopted at a rapid and increasing rate in the early 1980s, and since then at a decreased rate. It models the growth of a science park once established, showing significant effects on growth for the proximity to universities and other resources. The paper also reports university administrators' perceptions about the impact of their science parks on the academic missions of their universities. Statistical analyses show there is a direct relationship between the proximity of the science park to the university and the probability that the academic curriculum will shift from basic toward applied research.
\end{abstract}

(C) 2003 Elsevier B.V. All rights reserved.

JEL classification: I2; L31; O32; R1

Keywords: Science parks; Innovation; University/industry relationships

\section{Introduction}

While there is a growing body of knowledge regarding university-industry

\footnotetext{
*Corresponding author. Tel.: + 1-603-646-2941; fax: +1-603-646-2122.

E-mail addresses: al_link@uncg.edu (A.N. Link), john.t.scott@dartmouth.edu (J.T. Scott). 
research partnerships, ${ }^{1}$ there are few studies of university-industry strategic alliances in science parks. In this paper, we first describe the establishment and growth of a prominent sample of science parks that were among those operating in the United States at the end of the twentieth century. We then characterize, using survey data collected from a sample of major research universities in the United States, the perceptions of university administrators about the impact of science parks on various dimensions of the academic mission of a university. We relate those data about perceptions statistically to university and science park characteristics. Those characteristics include the distance of the park from the university and the formality of the relationship between the park and the university. Other characteristics are the R\&D budget of the university and the percentage of its faculty engaged in research with science park organizations, the percentage of total academic R\&D financed by industry, whether the university is public or private, the age of the park, and the technologies pursued by faculty associated with the park.

Surprisingly, given their long history in the United States as well as in other countries, there is no generally accepted definition of a science park. One definition has been posited by the Association of University Related Research Parks (AURRP). ${ }^{2}$ As stated in their Worldwide Research \& Science Park Directory, 1998 (AURRP, 1997, p. 2): ${ }^{3}$

\footnotetext{
${ }^{1}$ Much of this literature is reviewed in Hall et al. (2000, 2003), forthcoming) and in the papers in Siegel et al. (2001). Formal university participation in industrial research joint ventures has increased steadily since the mid-1980s (Link, 1996), the number of university-industry R\&D centers has increased by more than 60 percent during the 1980s (Cohen et al., 1997), and a recent survey of U.S. science faculty revealed that many desire even more partnerships with industry (Morgan, 1998). Mowery and Teece (1996, p. 111) contend that such growth in strategic alliances in R\&D is indicative of a "broad restructuring of the U.S. national R\&D system."

${ }^{2}$ In 2002, the Association was renamed the Association of University Research Parks (AURP).

${ }^{3}$ More narrowly, the U.S. General Accounting Office (GAO, 1983, p. ii) defines university-related research parks as "clusters of high technology firms or their research centers located on a site near a university, where industry occupancy is limited to research-intensive organizations." The lack of a standard definition of a science park is not unique to the United States. As Monck et al. (1988, p. 62) point out: "There is no uniformly accepted definition of a Science Park [in Britain] and, to make matters worse, there are several terms used to describe broadly similar developments - such as 'Research Park,' 'Technology Park,' 'Business Park,' 'Innovation Centre,' etc.' The United Kingdom Science Park Association (UKSPA, 1985, p. ii) defines a science park in terms of the following features: "A science park is a property-based initiative which: has formal operational links with a university or other higher education or research institution; is designed to encourage the formation and growth of knowledge-based businesses and other organizations normally resident on site; has a management function which is actively engaged in the transfer of technology and business skills to the organizations on site."
} 
The definition of a research or science park differs almost as widely as the individual parks themselves. However, the research and science park concept generally includes three components:

- A real estate development

- An organizational program of activities for technology transfer

- A partnership between academic institutions, government and the private sector.

'Science park' has evolved to become a generic term which refers to parks with some or all of the foregoing characteristics. Included under this rubric are-and these designations are subjective-research parks with a majority of tenants that are heavily engaged in basic and applied research. As well, science parks include technology parks with a majority of tenants that are heavily engaged in applied research and development. Technology or innovation parks often house new start-up companies and incubator facilities. ${ }^{4}$ Finally, commercial or industrial parks typically have tenants that add value to R\&D-based products through assembly or packaging, rather than do R\&D. However, we prefer the generic term science park since each of the classifications above does include some of the characteristics noted in the AURRP definition.

Fig. 1, based on the 1998 Directory, the most complete directory published by AURRP to date, illustrates the historical growth for the AURRP's U.S. science parks, as defined by the date at which each park was founded. ${ }^{5}$ The AURRP Directory's set of parks is just one sample of U.S. science parks. ${ }^{6}$ Notable in Fig. 1 are the following parks: Stanford Research Park (established in 1951), Cornell Business \& Technology Park (established in 1952), and the Research Triangle Park of North Carolina (established in 1959). We examine the foregoing set of science parks that have been formed in the United States since 1950 - the AURRP membership - to establish a few simple facts about the establishment and growth of science parks.

\footnotetext{
${ }^{4}$ Incubator facilities house pre-start-up companies. Often, when the science park is tied to a state university, the state underwrites the cost of operating the incubator facility as part of a regional economic development strategy.

${ }^{5}$ Year of establishment is only one metric for dating the age and subsequent growth of science parks in the United States. It, like other metrics, is less than perfect since the date of establishment of a park may not be the date at which the first organization established itself in the park. In the case of the Research Triangle Park of North Carolina, the first tenant committed to the Park in 1965 (Link, 1995, 2002; Link and Scott, 2003) six years after the Park was formally established.

${ }^{6}$ Without an accepted definition of what a park is, without the complete population, and without a field-tested taxonomy of science parks, however, we do not know if the characterization of the establishment and growth of science parks that comes from examining the AURRP membership is a characterization of science parks more generally.
} 


\section{Science Parks in the United States from 1951-1998}

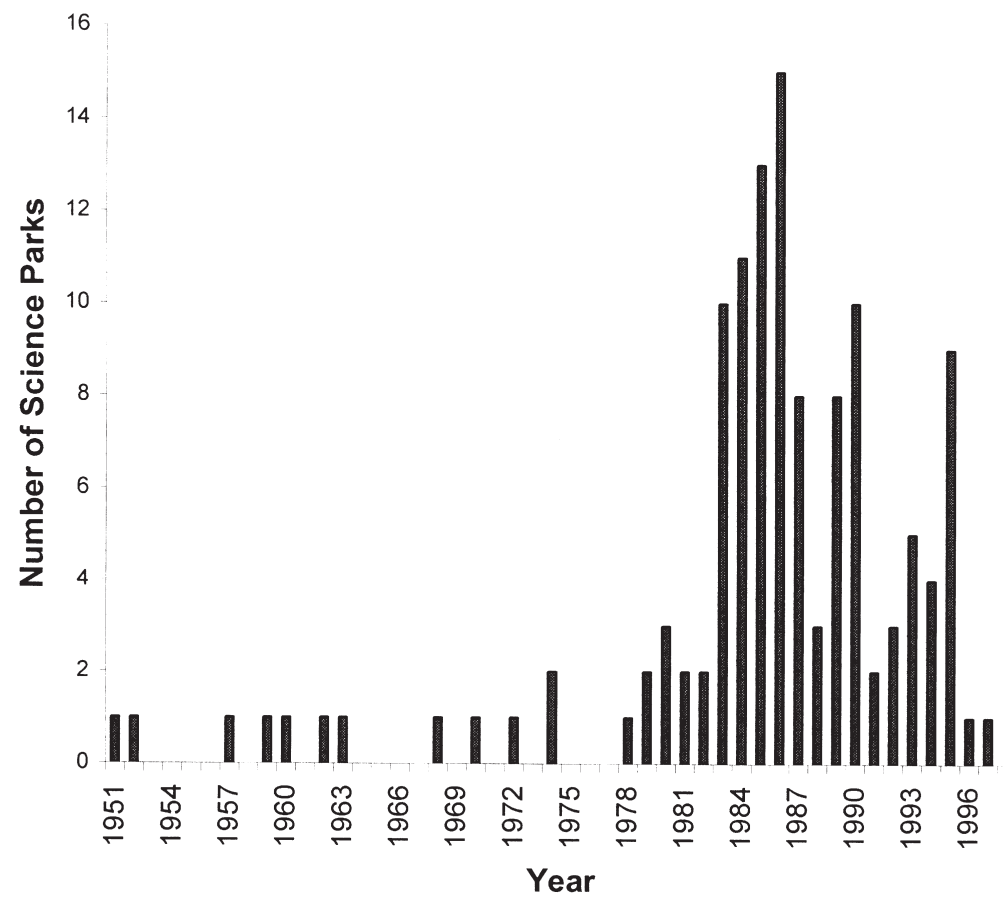

Fig. 1. Science Parks in the United States from 1951 to 1998.

Few scholars or researchers have studied science parks in any systematic manner. ${ }^{7}$ A number of studies have examined the influence of being in a science

\footnotetext{
${ }^{7}$ There have, however, been a number of important and carefully done historical studies of the formation and/or growth of science parks. Castells and Hall (1994) and Saxenian (1994) describe the Silicon Valley (California) and Route 128 (around Boston) phenomenon; Luger and Goldstein (1991), Link (1995, 2002), and Link and Scott (2003) detail the history of Research Triangle Park (North Carolina); Gibb (1985), Grayson (1993), Guy (1996a,b), and Vedovello (1997) summarize aspects of the science park phenomenon in the United Kingdom; Gibb (1985) also chronicles the science park phenomenon in Germany, Italy, Netherlands, and selected Asian countries; and Chordà (1996) reports on French science parks, Phillimore (1999) on Australian science parks, and Bakouros et al. (2002) on the development of Greek science parks.
} 
park on various aspects of firm performance (e.g., growth and R\&D productivity). ${ }^{8}$ However, after describing the U.S. experience with the establishment and growth of the modern science park, this paper provides, in an exploratory manner, the first systematic insights into the influence of industry in science parks on the academic missions of universities.

\section{Emergence and growth of U.S. science parks}

\subsection{Diffusion of the science park innovation}

If the cumulative total for the science parks shown in Fig. 1 is plotted against time, the familiar logistic curve results. ${ }^{9}$ In this section we offer an analytical model to characterize the 'lazy-S,' S-shaped pattern of the cumulative total of parks through time. We argue that the observed pattern of the establishment of science parks should be interpreted in terms of a model of the adoption of an innovation. Specifically, we posit the appearance of a new park as a new adoption of the innovative environment of a science park. We demonstrate that the establishment of science parks can be seen in terms of a simple model of diffusion, thereby offering support for this conceptualization and for how one might think of, and possibly forecast, the growth of the numbers of science parks in existence.

We have chosen a Gompertz survival-time model for our analytical demonstration because the model is quite simple and yet more general than a model using the exponential distribution that has a constant hazard rate. Geroski (2000)

\footnotetext{
${ }^{8}$ See Monck et al. (1988); Sternberg (1990); Westhead and Storey (1994); Westhead and Cowling (1995); Westhead et al. (1995); Westhead (1997); Westhead and Batstone (1998); Löfsten and Lindelöf (2002); and Siegel et al. (2003). Implicitly, policy makers assume that science parks do add value to firm performance, as well as to local community development, as evidenced by the recent National Research Council studies of the proposed Sandia Science Park and Ames Research Center (Wessner, 1999, 2001). As Massey et al. (1992, p. 56) point out, the 'environmental focus' that others have taken has merit:

At the core of the science-park phenomenon lies a view about how technologies are created. This view is that scientific activities are performed in academic laboratories [and Massey et al. assume that at the core of a science park is a university] isolated from other activities. The resulting discoveries and knowledge are potential inputs to technology. Science provides break-throughs from which new technological goods may spring. ... The argument goes that universities have many brilliant people making new discoveries but that they lack the means or the will to reach out to the market. Science parks constitute a channel by which academic science may be linked to commerce [emphasis added]. Thus science parks are there to promote, not 'science,' but its application in technology.

${ }^{9}$ Danilov (1971) attributes the relatively long period from about 1960 to the early 1970 s, during which the science park movement seemingly stalled, to a number of park efforts that failed as well as to restraints on corporate $\mathrm{R} \& \mathrm{D}$ growth because of a lackluster economy.
} 
discusses many distinct reasons for S-shaped diffusion curves, and he observes that different reasons suggest different distributions for describing adoptions of innovation. For example, when there are asymmetries in the speed of diffusion among different groups in the population of adopters, the Gompertz distribution has been used. ${ }^{10}$ The Gompertz survival-time model allows the data to represent a monotonically increasing or decreasing hazard rate for the adoption of the innovation - the appearance of a group of research companies in the innovative environment of a new science park. We hypothesize that as understanding of the science park innovation and the importance of interaction between industry and university science increased over the last half century, the hazard rate (described fully below) for adopting the science park innovation has increased.

The Gompertz model we estimate describes the adoption of the science park innovation as a stochastic diffusion process with an increasing hazard rate. Alternatively, the Weibull distribution could be used with the survival time model and also allow estimation of a hazard rate that increases or decreases through time. The log-normal or log-logistic distributions could be used for data with hazard rates that initially increase and then decrease, and the generalized gamma model would allow for even more flexibility in the hazard function. ${ }^{11}$ For our purposes, the Gompertz model offers the appropriate flexibility with a simple functional form to describe the S-shaped diffusion curve where the hazard rate for the population of adopters of the innovative environment increased over time. ${ }^{12}$

Our time series of adoptions of the science park innovation, for our sample of AURRP members in the United States, runs from 1951 when the first park was established until the most recent adoptions in our data that occurred in 1997. In the absence of any particular event that precipitated the awareness of the concept of a science park, we assume that in 1950 potential adopters of the science park concept are made aware of the possibilities. Then, through time science parks appear with appearances being most likely in the environments most favorable to the success of a science park.

The probability that an adoption of the innovation-the establishment of a

\footnotetext{
${ }^{10}$ See Geroski (2000); in particular, see his discussion there of Dixon (1980) and Davies (1979).

${ }^{11}$ StataCorp (2001), pp. 343-75) describes the alternative distributions, and the implementation of the Gompertz distribution for use as an estimable parametric survival-time model. Rather than using maximum likelihood techniques to estimate survival-time models using various distributions as we do here, the early literature on the diffusion of innovations imposed the logistic S-curve for the diffusion of an innovation using appropriate transformations to reach a functional form that could be estimated with relatively simple estimation techniques. See Geroski (2000) for a tracing of the literature from the pioneering studies to the later ones that have modeled hazard rates.

${ }^{12}$ The implementation of the Gompertz distribution for use as an estimable parametric survival model is described in StataCorp (2001, p. 351-2), and we provide a brief explanation here as well. Our estimation uses the procedures and software described in StataCorp (2001, pp. 343-75).
} 
science park-will have occurred by time $t$ is:

$$
F(t)=1-S(t) .
$$

$S(t)$ is the probability that for a particular adopter, the adoption has not occurred by time $t$ :

$$
S(t)=e^{\left(-e^{\lambda / \gamma}\right)\left(e^{\gamma t}-1\right)}
$$

The hazard rate for the adoption is:

$$
h(t)=F^{\prime}(t) /(1-F(t)),
$$

where

$$
F^{\prime}(t)=-S^{\prime}(t)=e^{(\lambda+\gamma t)-\left(e^{\lambda} / \gamma\right)\left(e^{\gamma t}-1\right)} .
$$

Substituting (1), (2), and (4) into (3), the hazard rate for adoption is then:

$$
h(t)=e^{\lambda+\gamma t}=e^{\lambda} e^{\gamma t},
$$

and the hazard rate is increasing, decreasing, or constant as $\gamma$ is $>,<$, or $=0$.

The hazard rate is the conditional probability density for adoption of the science park innovation. Conditional on an incipient group of potential investors not yet having adopted the innovative environment of a science park, the probability that it will adopt the innovation and establish a park during the small interval of time $\mathrm{d} t$ is given by $h(t) \mathrm{d} t$. The parameter $\lambda$ determines the base level of the hazard rate throughout the history of the second half of the twentieth century, while the parameter $\gamma$ determines the rate at which that base level grows through time. The survival-time model that we use to describe the history of science parks as the diffusion of an innovation treats the parameter $\lambda$ as a constant plus a linear combination of explanatory variables that have had an impact on the diffusion of science parks.

For the Gompertz diffusion model that we estimate, we have a proportional hazard model where the hazard $h\left(t_{j}\right)$ for the $j$ th adopter is:

$$
h\left(t_{j}\right)=e^{x_{j} \beta} e^{\gamma\left(t_{j}\right)} .
$$

The vector of explanatory variables for the $j$ th observation is denoted as $\mathbf{x}_{j}$. The parameters in the vector $\boldsymbol{\beta}$ and the ancillary parameter $\gamma$ are estimated from the data with a maximum likelihood estimator. We find that the ancillary parameter $\gamma$ is significantly greater than zero; thus, the hazard rate for adoption has increased throughout the fifty-year period.

Using the data provided in AURRP (1997), we estimate the model to describe the historical experience in the United States. The presence of a medical center or the park having aerospace/aeronautics among its technologies has a significant positive effect on the hazard rate. Park technology in the biotechnology/bio- 
medical area significantly reduces the hazard rate, reflecting the historical fact that while aerospace emerged relatively early in the half century of science park emergence, biotechnology emerged as an important area for industrial investment more recently. On the whole, the hazard rate for a park in the South or the Northeast exceeded that for a park in the West or the Midwest. ${ }^{13}$

To help intuition about the model, we present the results of the model as hazard ratios for each variable. The hazard ratio for an explanatory variable shows the effect on the hazard rate given a one-unit change in the variable while all other variables remain unchanged. From Eq. (6), the hazard ratio for variable $z$ among the several in $\mathbf{x}_{j}$ is then:

$$
\left(h\left(t_{j} \mid z+1\right)=e^{x_{j} \beta} e^{\gamma\left(t_{j}\right)} e^{\beta_{z}}\right) /\left(h\left(t_{j}\right)=e^{x_{j} \beta} e^{\gamma\left(t_{j}\right)}\right)=e^{\beta_{z}}
$$

The model is estimated using the 77 science parks for which data about the technologies were available. The model is estimated with robust standard errors, accounting for the fact that the same 'subjects' appear repeatedly in the pools of 'subjects at risk'. 14 With the interpretation we provide, the statistics in Table 1 show the historical picture for the emergence of science parks. Note that the $z$

Table 1

Gompertz survival time model of the diffusion of science parks ${ }^{\mathrm{a}}$

\begin{tabular}{lllrl}
\hline Explanatory Variable & Hazard Ratio & Robust Std. Error & $z^{\mathrm{b}}$ & Prob. $>|z|^{\mathrm{b}}$ \\
\hline Medical Center & 1.93 & 0.519 & 2.45 & 0.014 \\
$t 1$ & 1.74 & 0.467 & 2.08 & 0.038 \\
$t 4$ & 0.649 & 0.157 & -1.79 & 0.073 \\
South & 1.36 & 0.302 & 1.37 & 0.170 \\
Northeast & 1.61 & 0.465 & 1.66 & 0.097 \\
gamma & 0.180 & 0.0215 & 8.35 & 0.000 \\
\hline
\end{tabular}

Number of subjects $=77$, number of observations $=77$, number of failures $=77$, time at risk $=2607$, Wald chi-squared $(5)=10.6, \log$ likelihood $=8.38$, probability $>$ chi-squared $=0.0594$.

a The dependent variable or outcome is analytical time of the establishment of the park ('failure time' or 'analysis time when record ends'- thus, for the model, analysis time begins in 1950, and a science park that was established in 1983 has an analytical time of establishment of 33). The term 'failure' refers to traditional applications of the survival-time model and the 'survival' function, S. As long as a 'subject at risk' has not adopted the innovation by establishing a science park, it 'survives' in the data, but on adoption it ceases to 'survive' and leaves the set of potential adopters. $t 1=$ aerospace/ aeronautics; $t 4=$ biotechnology/biomedical; the remaining technology categories (in the intercept here in Table 1) provided in AURRP (1997) are provided in the note to Table 2 below where they are used.

${ }^{\mathrm{b}}$ The $z$ statistics and probability statements are for each of the underlying coefficients, rather than for the hazard ratios.

\footnotetext{
${ }^{13}$ The U.S. Census definitions for regions of the United States were used to assign states to one of the four regions-West, Midwest, South, and Northeast.

${ }^{14}$ StataCorp (2001, p. 281, p. 345).
} 
statistics and probability statements are for each of the underlying coefficients in $\boldsymbol{\beta}$, the vector of coefficients, rather than for the hazard ratios that are formed using those coefficients. ${ }^{15}$

The hazard ratios in Table 1 show that holding other things constant the hazard rate increases by 1.9 times if a medical center is present and by 1.7 times given aerospace/aeronautics technology. Reflecting its emergence later in the history of science parks, the hazard rate is 65 percent as great if biotechnology/biomedicine is indicated, other things the same. Because the model is estimated over the entire half of the century of the science park experience, the technology effects on the hazard rate, for the long-term historical S-curve for the diffusion of science parks, reflect the fact that aerospace investments were more likely earlier in the history, while biotechnology is more likely to be reported by parks formed later in the history. The model also shows that over the entire half of the century, the hazard rates for science parks are about 1.4 times as great in the South and 1.6 times as great in the Northeast as in the West and the Midwest. The AURRP (1997) data of course provide much more information about technologies and various other characteristics of parks, but for our statistical summary of the history, we have reported a very simple specification with just the effects that are statistically significant (or, in the case of the geographic effects, somewhat significant) in the presence of other effects. Our purpose at this point is not to document all of the detail of the history, but to use the simple model to provide a formal description that illustrates science parks as an innovation that diffused throughout the second half of the twentieth century.

The graph shown in Fig. 2 uses the estimated model to predict, for a science park with the characteristics of the average park in our sample, the probability that the innovation (the science park) will not have occurred by time $t$, where time is measured along the $x$-axis in analytic time from 0 to 47 which corresponds to calendar time from 1950 to 1997 . Fig. 3 shows the predicted hazard rate for the park with average characteristics. ${ }^{16}$ Subtracting from 1 the probability shown in Fig. 2 gives the probability that the innovation (the science park) has occurred by each time. ${ }^{17}$ Multiplying that probability by the number of science parks in our population gives the model's fitted logistic curve, shown in Fig. 4, that corresponds to the actual curve that could be plotted by cumulating the appearance of the parks as shown in Fig. 1. Instead of the actual result, the model is predicting the expected number of parks at each time, illustrating that their appearance has

\footnotetext{
${ }^{15}$ StataCorp (2001, pp. 354-355).

${ }^{16}$ The statistics show that the gamma parameter is significantly greater than zero, so the hazard rate is increasing over time. Thus, the Gompertz model is appropriate rather than the simple exponential model where the hazard rate is constant. The plot of the hazard rate against time for the average science park is shown in Fig. 3.

${ }^{17}$ Using the model's average estimation of lambda, -8.43 is the average for the sample of the linear combination of the estimated coefficients and the explanatory variables, and gamma, estimated to be 0.180 , we then have the probability of occurrence for the average park through time.
} 
12 Universities and the Entrepreneurial Ecosystem

1332 A.N. Link, J.T. Scott / Int. J. Ind. Organ. 21 (2003) 1323-1356

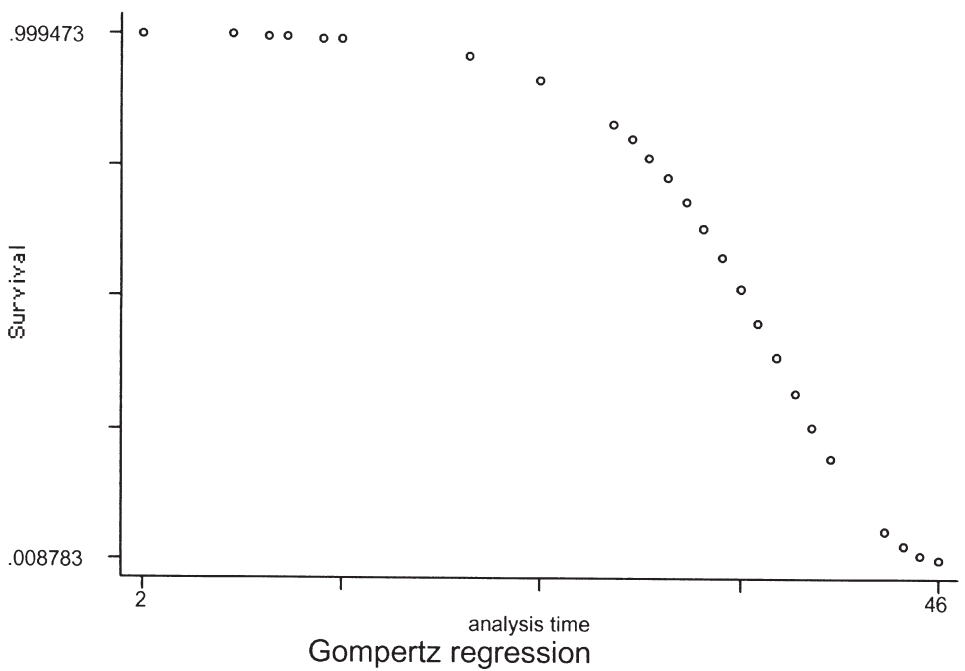

Fig. 2. The probability that the average science park would not have appeared by time $t$ for $t$ from 1950 to 1997.

followed the S-shaped logistic curve often associated with the diffusion of an innovation.

Using the date at which each new science park is established, we have a list of the 77 parks' arrival times starting with the earliest ones appearing in the early

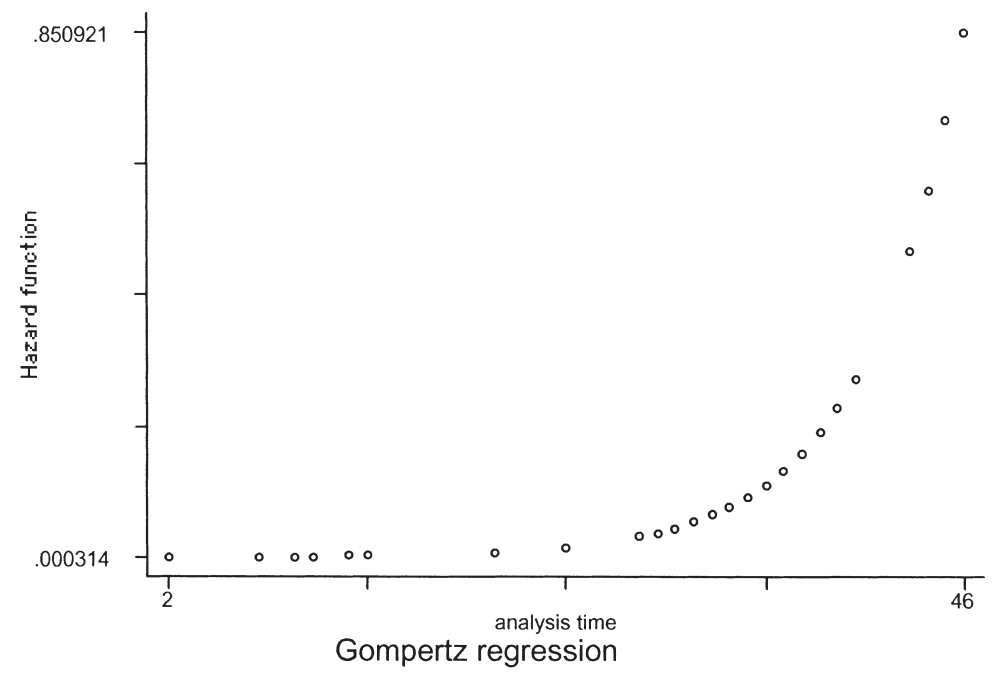

Fig. 3. Plot of the hazard rate as a function of time for the average science park. 


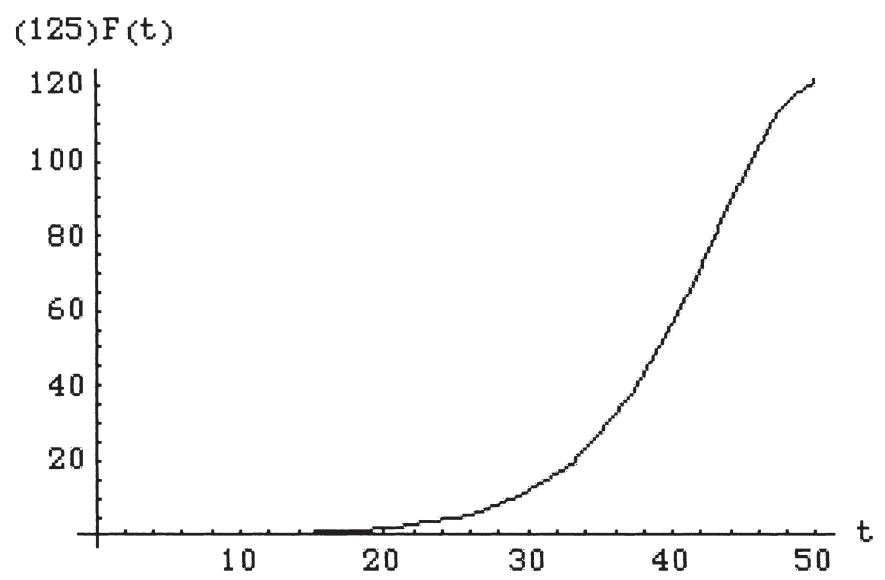

Fig. 4. The expected cumulative number of science parks by time $t$ for last half of the twentieth century.

1950 s, and ending with those appearing in the late 1990s. With that information, we were able to estimate $\lambda$ and $\gamma$ for the diffusion model showing the adoption of the science park research environment by successive groups of investors. On average for those groups, the model shows that $\lambda$ is estimated to be -8.43 and $\gamma$ is estimated to be 0.18 for the diffusion of the innovation - the science park. Thus, from Eq. (5), in 1950 at $t=0$ the hazard rate on average across the 77 groups of investors is $e^{-8.43}=0.00022$, and the hazard rate grows at the rate of 18 percent per year.

Fig. 4 raises a question that is important for the formation of technology policy. Has the adoption of the innovation of the science park run its course? Would public policy make possible the beginning of a new logistic curve, rising from the flat portion that both actual adoptions in Fig. 1 and the simulated ones in Fig. 4 suggest has followed half of a century of growth? ${ }^{18}$ The actual establishments of research parks as shown in Fig. 1 as well as our diffusion model's tracking of the history as shown in Fig. 4, suggest that public policy can have a large impact on the formation of science parks. From both Fig. 1 and Fig. 4, we see that the acceleration in the formation of science parks occurred after the passage of several technology initiatives in the early 1980s. These policies included, in chronological order, the Bayh-Dole Act of 1980 which reformed federal patent policy by providing increased incentives for the diffusion of federally-funded innovation results; the research and experimentation (R\&E) tax credit of 1981 which underwrote, through tax credits, the internal cost of increases in R\&E in firms; and

\footnotetext{
${ }^{18}$ Price (1963, Chapter 1) provides a seminal discussion of the appearance of new logistic curves in the history of science.
} 
the National Cooperative Research Act of 1984 which encouraged the formation of research joint ventures, as well as numerous state policies that coincided with the adoption of science parks. ${ }^{19}$ These technology policies, and others, were a public sector reaction to both the productivity growth slowdown that began in the early 1970s and to the associated precipitous decrease in the competitive position of many U.S. technology-based industries. Of course, the public policies, being more or less coincident with the growth in science parks, could reflect public policies that followed the actions of industry rather than policies that stimulated those actions.

New public policies that encouraged interactions between universities and industry could stimulate a new logistic curve, perhaps even a new fifty-year cycle of growth for science parks. Would such public policy be desirable? The answer is not obvious, but any new policies that foster partnerships between universities and research organizations - private, public, or non-profit-would certainly enhance the environment conducive for partnering within science parks. As for the social desirability of such an environment, that depends on the costs of the new policies and on the size of the net benefits from cooperation, benefits that might include shortened research time and reduced research costs. Are the effects of newly directed commercial interests within science parks in the public interest? The answer will require developing understanding of the sources of growth for science parks, the effects that the parks have on both the economy and on the academic missions of universities, and the role of science parks in the U.S. innovation system.

\subsection{Growth of science parks}

Science parks are an innovation that reorganizes the method of applying scarce research resources to the production and application of knowledge by combining university and industry resources in a new way. As discussed in the introduction, Fig. 1 shows the adoption of science parks - reflecting the establishment and formation of the science park concept - throughout the last half of a century. We have modeled that adoption as the diffusion of an innovation, with the model estimating the logistic curve in Fig. 4.

In this section, we address the question: Once each park is established, how can we explain its growth over time? In particular, we are interested in developing initial stylized facts about the growth of science parks. To that end, we estimate a model describing the growth of a science park once the basic innovation of the park for combining and applying research resources has been adopted.

Our growth model is:

$$
y(t)=a e^{g t} e^{\varepsilon}
$$

\footnotetext{
${ }^{19}$ These initiatives are discussed in detail in Audretsch et al. (2002).
} 
where $y(t)$ is the science park's employment $t$ years after it was established, $a$ is the minimum efficient start-up scale for a science park, $g$ is the annual growth rate of the park, and $\varepsilon$ is random error.

The growth rate for the park is a function of various explanatory variables, $x_{1}$ to $x_{k}$ :

$$
\frac{\dot{y}}{y}=g=b_{0} x_{0}+b_{1} x_{1}+\cdots+b_{k} x_{k}
$$

We then have:

$$
\ln y(t)=\ln a+g t+\varepsilon
$$

Substituting, we have an estimable model:

$$
\ln y(t)=\ln a+b_{0} t+b_{1} x_{1} t+\cdots+b_{k} x_{k} t+\varepsilon
$$

Estimation of the growth model for the U.S. data is presented in Table 2. The coefficient on $t$ (the length of time that a park has been in existence) shows the annual growth rate for science parks to be 0.084 or 8.4 percent for the parks in the Northeast when none of the qualitative variables in our model are 'turned on'. The annual growth rates for the West, Midwest, and South do not differ significantly, ceteris paribus.

The coefficient on each of the remaining variables (each being the interaction of an explanatory variable and the time that the science park has existed) gives the variable's effect on the annual growth rate. The growth rate of science parks has varied with technologies and with park characteristics. There are controls for all technology effects (leaving 'other technologies' in the intercept) and all regional effects (leaving Northeast in the intercept). ${ }^{20}$

The variable $t p$ is a dummy variable that equals 1 if a park was established in 1980 or later during the period of technology policy initiatives. Thus, the coefficient on its interaction with the time a park has been in existence shows the difference in the annual average rate of growth for parks established after the passage of the aforementioned new technology policies. The coefficient is statistically significant and equal to 0.102 ; parks established after the passage of the new technology policies have annual growth rates that are higher by 10.2 percentage points, other things being the same.

Three park characteristics are robustly significant. (1) A knowledge environment variable: the driving distance (in miles) between the park and the nearest university, which has a negative effect on growth. For smaller mileage, the growth rate per year falls by the amount of about 10 percentage points for every 100 miles distance between the park and the nearest university. The effect diminishes as

\footnotetext{
${ }^{20}$ The technology areas are those reported to the AURRP, and the regional areas are again those described by the Census for the U.S.--Northeast, West, Midwest, and South.
} 
16 Universities and the Entrepreneurial Ecosystem

1336

A.N. Link, J.T. Scott / Int. J. Ind. Organ. 21 (2003) 1323-1356

Table 2

Explaining the growth of science parks*

\begin{tabular}{|c|c|}
\hline Variable & Coefficient (standard error) \\
\hline$t$ & $0.0842(0.0480)^{*}$ \\
\hline$t \times$ West & $-0.0194(0.0358)$ \\
\hline$t \times$ Midwest & $-0.0302(0.0385)$ \\
\hline$t \times$ South & $0.00800(0.0309)$ \\
\hline$t 1 \times t$ & $-0.0433(0.0373)$ \\
\hline$t 2 \times t$ & $-0.0837(0.0458)^{*}$ \\
\hline$t 3 \times t$ & $0.0635(0.0354)^{*}$ \\
\hline$t 4 \times t$ & $0.0160(0.0350)$ \\
\hline$t 5 \times t$ & $-0.148(0.0415)^{* * *}$ \\
\hline$t 6 \times t$ & $-0.0346(0.0275)$ \\
\hline$t 7 \times t$ & $0.0875(0.0385)^{* *}$ \\
\hline$t 8 \times t$ & $0.00817(0.0252)$ \\
\hline$t 9 \times t$ & $0.121(0.0313)^{* * *}$ \\
\hline$t 10 \times t$ & $0.0331(0.0394)$ \\
\hline$t 11 \times t$ & $-0.0266(0.0305)$ \\
\hline$t 12 \times t$ & $0.0113(0.0445)$ \\
\hline$t 13 \times t$ & $-0.0236(0.0304)$ \\
\hline$t 14 \times t$ & $0.115(0.0383)^{* * *}$ \\
\hline$t 15 \times t$ & $-0.0309(0.0313)$ \\
\hline$t 16 \times t$ & $-0.00146(0.0341)$ \\
\hline$t 17 \times t$ & $0.0796(0.0310)^{* *}$ \\
\hline Lease $\times t$ & $-0.0662(0.0258)^{* *}$ \\
\hline Venture-capital $\times t$ & $0.0692(0.0284)^{* *}$ \\
\hline Miles $\times t$ & $-0.00104(0.000374)^{* * *}$ \\
\hline Miles $^{2} \times t$ & $1.29 \times 10^{-6}\left(6.99 \times 10^{-7}\right)^{*}$ \\
\hline$t p \times t$ & $0.102(0.0363)^{* * *}$ \\
\hline constant & $3.21(0.604)^{* * *}$ \\
\hline
\end{tabular}

Number of observations $=51 ; F(26,24)=5.14 * * * ; R^{2}=0.848 ;$ adjusted $R^{2}=0.683$.

*The dependent variable, ln emp, is the natural logarithm of employment. The observations are for all science parks in the U.S. for which the data were available. The park technology categories are from AURRP (1997): $t 1=$ aerospace/aeronautics; $t 2=$ agriculture; $t 3=$ animal science; $t 4=$ biotechnology $/$ biomedical; $t 5=$ chemical; $t 6=$ communication; $t 7=$ computer; $t 8=$ electronics $/$ microelectronics; $t 9=$ engineering; $t 10=$ environmental; $t 11=$ information technology; $t 12=$ food processing; $t 13=$ life science; $t 14=$ medical related; $t 15=$ pharmaceutical; $t 16=$ software; $t 17=$ telecommunications; $t 18=$ other. Significance levels are denoted by * (10 percent), ** (5 percent), and *** (1 percent).

mileage increases. ${ }^{21}$ (2) A financial environment variable: 1 if venture capital funds are available and 0 otherwise, which has a positive effect on growth. The

\footnotetext{
${ }^{21}$ The negative sign on mileage and the positive sign on mileage squared imply the negative effects on growth of more miles bottoms out (and then turns up, but we believe the upturn is really outside the range of anything interesting or sensible). With $y=a+b x+c x^{2}+\ldots$, the first order condition $\mathrm{d} y / \mathrm{d} x=b+2 c x=0$ implies that the negative effect will bottom out at $-b / 2 c$ miles. So, for the growth model in Table 2, the strong negative effect for low mileage gradually diminishes until miles $=0.00104 / 0.0000026=400$ miles. There is only one observation among the 51 observations in the model for which a science park is more than 400 miles from the associated university.
} 
growth rate per year increases by the amount of 6.9 percentage points per year if the park reports that venture capital funds are available. (3) A real-estate management variable: having sites for lease only $(=1)$ as contrasted with having sites for sale and lease $(=0)$, which has a negative effect on growth. The annual growth rate is lower by 6.6 percentage points when parks report sites are leased rather than leased and sold.

Additionally, there are technology effects. Across technologies reported by the AURRP, the strongest statistically significant growth has come from computers, engineering, medical, and telecommunications technologies. The technologies showing the most pronounced negative growth rates are agriculture and chemicals.

The model also provides a stylized fact for the base size for a park. The constant term gives a stylized, initial estimate of the log of the minimum efficient start-up scale for a research park. Looking at the model in that way, we see that the minimum efficient scale is a park with 25 employees (the base to the natural logarithms raised to the power 3.21).

These are exploratory results; future research should consider other explanatory variables such as the extent and nature of faculty and university administration involvement with the university-related science park and whether clusters of universities affect the performance of science parks. Further, growth is just one metric for the success of a park, but it is probably not a bad metric for success. Presumably growth would be correlated with many other metrics for success that would be less easy to quantify (positive externalities affecting the regional economy or the entire economy, successful transfer to industry of university research, placement of university graduates, and so on).

\section{Science parks and the academic missions of universities}

\subsection{Sample of U.S. universities and the data collection process}

The population sample of U.S. universities selected for this study consists of the 88 academic institutions that are categorized both in the top 100 academic institutions as measured by $R \& D$ expenditures and as defined by the National Science Board (2000), and in the Carnegie extensive classification of doctoral/ research universities (Carnegie Foundation, 2001). Our priors were that this sample would contain a large segment of academic institutions located in or near science parks that have a research or technology park character, and that have significant interactions with park organizations. The population sample is shown in Table 3.

A brief survey was designed, pretested, and then sent electronically in 2001 to the provost's office at each of these 88 universities. The purpose of the 10 percent pretest $(n=9)$ was to ensure that a provost could answer our survey questions in 
Table 3

Sample of U.S. universities $(n=88)$

\begin{tabular}{|c|c|c|}
\hline Auburn U & SUNY Buffalo & NYU \\
\hline $\mathrm{U}$ of Alabama at Birmingham & SUNY Stony Brook & U of Rochester \\
\hline U of Arizona & North Carolina State & Yeshiva U \\
\hline UC-Berkeley & U of North Carolina & Duke \\
\hline UC-Davis & Ohio State & Case Western \\
\hline UC-Irvine & $\mathrm{U}$ of Cincinnati & Carnegie Mellon \\
\hline UCLA & U of Oklahoma & U of Pennsylvania \\
\hline UC-San Diego & Oregon State & Vanderbilt \\
\hline UC-Santa Barbara & Penn State & \\
\hline Colorado State & U of Pittsburgh & \\
\hline U of Colorado & Clemson U & \\
\hline $\mathrm{U}$ of Connecticut & $\mathrm{U}$ of Tennessee & \\
\hline Florida State & Texas A\&M & \\
\hline U of Florida & $\mathrm{U}$ of Texas-Austin & \\
\hline U of South Florida & U of Utah & \\
\hline Georgia Tech & Utah State & \\
\hline U of Georgia & $\mathrm{U}$ of Virginia & \\
\hline U of Hawaii & Virginia Tech & \\
\hline U of Illinois, Chicago & $\mathrm{U}$ of Washington & \\
\hline U of Illinois, Urbana-Champaign & Washington State & \\
\hline Indiana U & $\mathrm{U}$ of Wisconsin & \\
\hline Purdue U & Cal Tech & \\
\hline Iowa State & Stanford & \\
\hline U of Iowa & U of Southern California & \\
\hline U of Kansas & Yale & \\
\hline U of Kentucky & Georgetown & \\
\hline LSU & U of Miami & \\
\hline U of Maryland, Baltimore County & Emory U & \\
\hline U of Maryland, College Park & Northwestern & \\
\hline U of Massachusetts & U of Chicago & \\
\hline Michigan State & Tulane & \\
\hline $\mathrm{U}$ of Michigan & Johns Hopkins & \\
\hline Wayne State & Boston $\mathrm{U}$ & \\
\hline U of Minnesota & Harvard & \\
\hline Mississippi State & MIT & \\
\hline U of Missouri & Tufts & \\
\hline U of Nebraska & Washington $\mathrm{U}$ & \\
\hline Rutgers & Princeton & \\
\hline New Mexico State & Columbia & \\
\hline U of New Mexico & Cornell & \\
\hline
\end{tabular}

an informed manner and to ensure that questions were phrased in an unambiguous manner. Follow-up telephone surveys were made to all non-respondents.

A variety of information was requested (discussed below), but the primary goal of the survey was to collect qualitative information regarding the provost's 
perception of the impact of the university's involvement with science parks on the following six academic missions: ${ }^{22}$

- research output, measured in terms of publications

- research output, measured in terms of patents

- extramural research funding

- applied versus basic nature of the curriculum

- placement of doctoral graduates

- ability of the university to hire preeminent scholars.

Motivating this inquiry is not only the conspicuous void of information about science parks in general and about technology flows from organizations into universities in particular, but also the need to understand how those flows affect fundamental academic behavior. Nelson (2001), for example, has asked if universities can take on the role of 'commercial enterprises' (e.g., licensing and patenting) without jeopardizing their more traditional roles such as their commitment to publish in the public domain and contribute to public science.

We received 47 responses (electronic and telephone), representing an initial response rate of 53.4 percent. However, 18 universities responded that they currently have no relationship with a science park and that the survey was therefore not relevant to them. Our final sample, which is analyzed in this paper, consists of the remaining 29 of the 47 responding universities, representing an overall usable response rate of 33.0 percent. Each of the 29 science parks is either a research park or a technology park, using the taxonomy above.

Table 4 shows the distribution of responses to statements about the influence of science parks on the academic missions of the university. Two general patterns are clear from the distribution of responses. First, there is more agreement than disagreement (e.g., more 4 and 5 responses than 1 and 2 responses) that involvement with a science park positively affects the research output and extramural research funding of universities. Second, there is more disagreement than agreement that such involvement affects the placement of doctoral graduates and improves the ability of the university to hire preeminent scholars.

\footnotetext{
${ }^{22}$ A concern prior to administering the survey was whether a provost (including the resources the provost could draw upon) could meaningfully provide such information. During the pretest phase of the study we specifically explored this issue and found in all cases that there was institutional knowledge about the university-science park relationship, even in cases where the provost was only recently appointed. Further, during the follow-up telephone interviews, each respondent was asked whether non-response to the electronic survey was in any way because of ambiguity in the survey or an inability to respond accurately to the survey statements. Also, we discussed with the provosts involved in the pretest stage the appropriateness of the six academic mission statements.
} 


\subsection{Quantitative analysis of the impact of science parks on the academic missions of universities}

To address the general question of how a science park relationship affects the academic missions of a university, we estimated six ordered probit models using the data collected from our survey. The left-hand-side variable in each of the models is a Likert-scale response variable; hence, the ordered probit model is the appropriate statistical technique. Each model was specified to explain interuniversity differences in the extent to which provosts agreed or disagreed with the academic mission statements referenced in Table 4. Greater agreement with a mission statement is associated with a higher score; for example, a higher score for the first question means greater enhancement of the university's academic mission of creating research publications. The extent of agreement is modeled as a function of characteristics of both the university and the science park with which the university is affiliated.

Our models initially focused on the same set of independent variables as represented in the model:

$$
\text { academic mission }=f(\text { relationship, mileage, } r d, \mathbf{X})
$$

where academic mission represents each provost's response to each of the six academic mission statements, and where the independent variables will be discussed below. Thus, we estimated six versions of Eq. (12), one corresponding to each survey statement summarized in Table $4 .^{23}$

Regarding the independent variables in Eq. (12), relationship dichotomizes the structure of each university's relationship with its science park. The variable formal equals one when the relationship is formal, and it equals zero if it is informal. Two questions on the survey quantify this: "Does your university have a formal relationship with a science park? (By 'formal' we intend any institutionally recognized arrangements, such as contractual arrangements of various sorts between your university and the science park.)" ${ }^{24}$ Or, "Does your university have an informal relationship with a science park? (By 'informal' we intend individual rather than institutional relationships, for example, contract research between faculty members and the science park that is not contracted through the university

\footnotetext{
${ }^{23}$ Alternative econometric approaches to the general question of how a university's relationship with organizations in a science park affects the academic missions of the university were considered. Those alternatives are discussed in the Appendix.

${ }^{24}$ Following this question we asked: If YES, what is the name of the science park and what is the nature of your formal relationship (e.g., joint research with selected organizations, joint appointments of faculty at a research institute, own the land the park is on, lease buildings to research companies in the park, etc.)?
} 


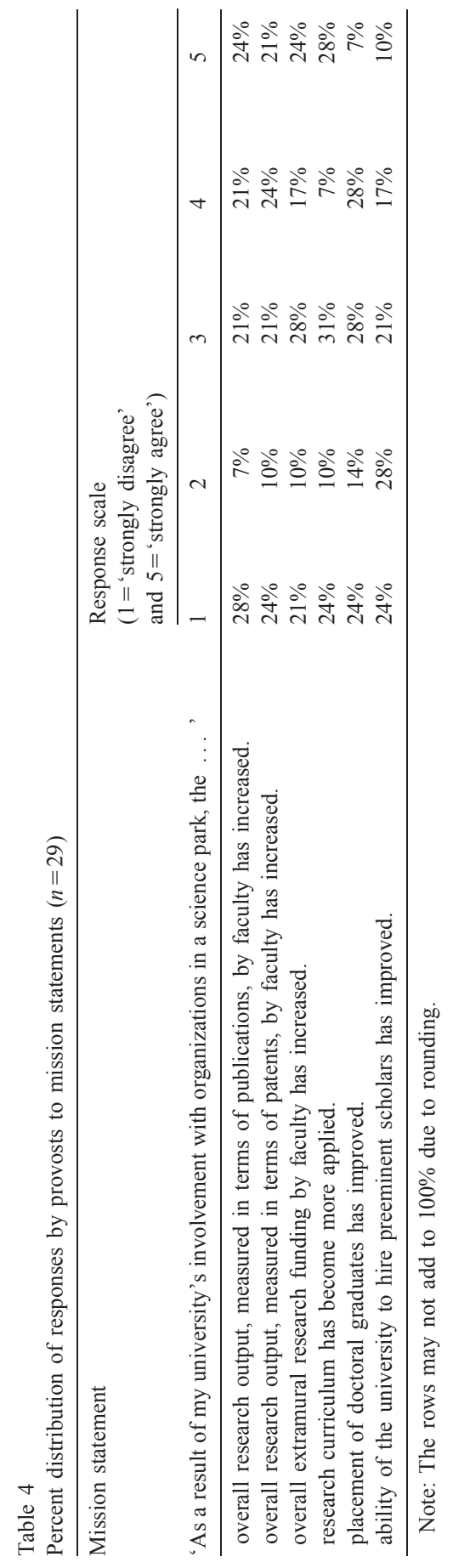


but treated as individual consulting.) ${ }^{25}$ We hypothesize that a formal relationship between a university and a science park leads to greater control over the interaction between faculty and the organizations in the park, much like in a centralized decision-making firm. Thus, where formal relationships exist the university may be able to exercise greater influence over the entrepreneurial direction that faculty take and how organizations in the park interact with the university as a whole. To the extent that a formal relationship overcomes barriers to faculty-organization interactions, it may reveal itself as greater faculty research output, greater placement of doctoral graduates, and a greater ability for the university to hire preeminent scholars.

The variable mileage - the miles between a university and its associated science park-quantifies the geographical relationship between the university and the science park. ${ }^{26}$ Adams and Jaffe (1996) suggest that communication costs related to collaborative R\&D activity increase with distance. Wallsten (2001) shows that geographical proximity to other successful innovative firms, as evidenced by the firm receiving a Small Business Innovation Research (SBIR) award, is associated with a firm's own success. These papers, as well as the works of Feldman (1999), Feldman and Lichtenberg (2002), and Adams (2002) motivate the inclusion of the variable mileage; we hypothesize that the closer a science park is to the university the more innovative the university. In the context of our model, mileage should thus enter negatively in the research output and extramural research equations. We also expect it to enter negatively in the curriculum equation, expecting a closer science park to have a bigger impact on a university's applied research since that is the research area common to both the university and the organizations in the park.

The variable $r d$ is a scale variable, distinguishing universities in terms of their total research and development budget in millions of dollars. ${ }^{27}$ Following Cohen and Levinthal (1989), we conjecture that more R\&D-active universities may have a greater capacity to absorb the knowledge gained through research relationships with organizations in a science park. Thus, we hypothesize that such universities will benefit, in a research sense, relatively more from a relationship with a science park, and this absorption will show itself in more basic research and related research output.

Vector $\mathbf{X}$ controls for other university and firm characteristics. Two technology dummy (i.e., set to equal either one or zero) variables are included in the empirical

\footnotetext{
${ }^{25}$ Following this question we asked: If YES, what is the name of the science park and what is the nature of your informal relationship (e.g., joint research or faculty members who have consulting positions with selected businesses or a research institute; have an incidental, real estate relationship with the science park but no formal joint effort between the university and the tenants to develop the park in ways that integrate the tenants' activities with the university's research resources; etc.)?

${ }^{26}$ Data on mileage between a university and its named science park came from Internet information about the university or about the park.

${ }^{27}$ These data came from National Science Board (2000, p. A-315).
} 
specifications. Each provost was asked on the survey what technology(ies) are being investigated by faculty involved in research with science park organizations. The variable $d I T$ equals 1 if information technology was mentioned, and dbiotech equals 1 if biotechnology was mentioned. Multiple technologies were generally mentioned; however, no significance was given to the order in which they were mentioned.

Provosts were also asked to approximate the percentage, perinresrch, of faculty who are routinely involved in research with science park organizations. That percentage is a scale variable approximating the proportion of faculty who could be the recipients of a reverse knowledge flow from industry into the university. The reverse flow of knowledge could have an impact on the university's academic missions.

The variable agepark is the age of the science park with which each university interacts, measured as the number of years between the time of the survey (in late 2000 with telephone follow-ups well into 2001) and the year that the named science park was formed. ${ }^{28}$ This variable is designed to control for the development over time of park organizations with which the university could interact as well as the development of the quality of the interactions - a process that takes time. However, it is an imperfect control for this purpose, although no better information is available, since a park may not begin to have organizations enter immediately upon its formation.

In addition to the university and park characteristics described above, we also control for response bias. As seen in Table 5, the sample of 29 responding and reporting universities does not perfectly mirror the population sample of 88 universities in terms of the selected key characteristics. To control for differences in the probability of responding to the survey, we estimated the probability of responding and completing the survey, that is, the probability of selection into the

Table 5

Selected mean values, by sample of universities

\begin{tabular}{lcc}
\hline University characteristics & Population sample $(n=88)$ & $\begin{array}{l}\text { Responding sample } \\
(n=29)\end{array}$ \\
\hline $\begin{array}{l}\text { Park on campus } \\
\text { (parkoncampus) }\end{array}$ & $54.55 \%$ & $65.52 \%$ \\
$\begin{array}{l}\text { Total academic R\&D } \\
(r d) \\
\% \text { of total academic R\&D from industry }\end{array}$ & $13.57 \%$ & $\$ 207.07 \mathrm{M}$ \\
$\begin{array}{l}\text { indrd }) \\
\% \text { public universities } \\
(\text { pubpriv }=1 \text { if public; 0 otherwise) }\end{array}$ & $69.32 \%$ & $15.00 \%$ \\
\hline
\end{tabular}

\footnotetext{
${ }^{28}$ In 27 of 29 parks we could identify the year the park was formed using information from the Internet and from AURRP (1997).
} 
sample of 29 , prob8829..$^{29}$ That probability is then used as a control variable in Eq. (12). ${ }^{30}$ We believe that this variable is doing more than simply controlling for the effect of a correlation in random errors in the model of response and complete models of the provosts' perceptions about the effects of science parks on academic missions. Our model of perceptions is exploratory and unlikely to be complete with just the variables other than prob8829. We view the variable prob8829 as capturing substantive effects of the complete model that otherwise would be left in the error term and that are related to the probability of responding to the survey.

Table 6 shows the econometric results for the six ordered probit models to assess the determinants of inter-university differences in the impact of science park relationships on the academic missions of universities. The specifications presented are for the parsimonious models that include (apart from the response control) only the explanatory variables that had coefficients at least as great as their standard errors when each model was estimated with all of the explanatory variables. As we have presented in the conference versions of this paper, remarkably (given the small number of observations and the large number of explanatory variables) the full specifications with every one of the explanatory variables included show essentially the same results regarding the significant variables presented in Table 6 . The variables omitted in Table 6 had insignificant coefficients, but their inclusion in the all-inclusive models did not eliminate the significance or change the signs of the other variables as presented in Table 6's parsimonious models. Given the small number of observations and the exploratory

\footnotetext{
${ }^{29}$ The probit estimates used to calculate prob8829 came from a model of the probability of selection into the sample of 29 respondents among the 88 universities surveyed. The explanatory variables for the probit model of selection were parkoncamp, indrd, and pubpriv. Each explanatory variable had a positive impact on the probability of response to the survey. Although the coefficients were not very significant individually, the probabilities predicted by the model are important in explaining the provosts' responses to some of the mission statements.

${ }^{30}$ Alternatively, the hazard rate from the probability of response model can be used to control for systematic components in the error that are associated with selection into the sample. Results are similar using the hazard rate rather than the probability of selection. We prefer to control for the possibility that something in the error is associated with the selection into the sample by using the probability of response directly. The specifications for our models are exploratory, and Maddala (1983, p. 269) points to evidence "that the normal selection-bias adjustment is quite sensitive to departures from normality." The use of the probability of response rather than the hazard rate has straightforward, intuitive meaning that is not dependent on an assumption of joint normally distributed disturbances for the response probit and the ordered probit models. Further, the standard approach to selection bias of course depends on complete models for response and for the substantive model of interest-here the model of university administrators' perceptions. The response term in the later model then captures the effect of correlation in the random errors in the two models. As discussed in the text, we view the variable prob8829 as completing our substantive model, capturing systematic effects on the academic missions that vary with characteristics of universities that are associated with the probability of response. Those ultimate causal characteristics may not be those in our response model, but rather associated with them and therefore with response.
} 
nature of the models, our preferred specifications are the parsimonious ones shown in Table 6.

Ceteris paribus, universities with a formal relationship with a science park realize greater benefits from that relationship as quantified through increased publication and patenting activity, greater extramural funding success, and through an enhanced ability to hire preeminent scholars and to place doctoral graduates.

The closer geographically a university is to the science park, ceteris paribus, the greater the university's success obtaining extramural funding, the greater the influence of park tenants on the applied versus basic research nature of the university's curriculum, and the greater the ability of the university to place its doctoral graduates. The effects are stronger the closer the university and the science park are to one another, and the attenuation of the effect associated with increasing mileage should be considered for ranges reasonably near the sample means. The finding about the applied research curriculum is revisited below. ${ }^{31}$

The total R\&D budget of the university, $r d$, enters significantly in three cases. It enters positively in the patenting equation meaning that, ceteris paribus, more R\&D-active universities have their patenting activity positively influenced by their association with a science park, supporting the hypothesis about absorptive capacity. It enters negatively in the extramural funding equation, as well as in the hiring equation. We interpret the latter two findings to suggest that the R\&D activity of the university, rather than its science park affiliation, drives its academic reputation as reflected through enhanced funding and hiring. The effect of $r d$ is explored further below.

The results in Table 6 also suggest (keeping in mind the caveats associated with agepark) that older parks have an applied influence on the university's research curriculum, perhaps also explaining the positive effect of age on patenting. Older parks are also more likely to have a positive influence on the hiring of preeminent scholars. The percentage of faculty engaged in university/science park activities, which like $r d$ is a scale variable, also enters significantly in the publications equation.

The probability of responding to the academic mission statements, prob8829, enters somewhat significantly in the publications model, the patents model, and the

\footnotetext{
${ }^{31}$ Note that there are two models with the nonlinear mileage effect, and the negative effect in the first case - for extramural funding - bottoms out at $0.0951 / 0.005=19$ miles, but recall that the sample mean for the sample of responding firms is only 5.7 miles. For the range around the mean where it is sensible to simulate the effect, the effect is negative. In the second case, the effect bottoms out at $0.942 / 0.034=$ 28 miles. The effect estimated is negative and diminishing. Think of a negatively sloped curve that gradually bottoms out and approaches an asymptote. It is very sensible that as distance gets bigger, the marginal negative effect would diminish, but we think that mathematical upturn is not of interest empirically given the sample means. Just 4 of the 29 responding parks are further than 19 miles and just 2 of the 29 (and of the 27 used in the applied research model) are further than 28 miles.
} 
1346 A.N. Link, J.T. Scott / Int. J. Ind. Organ. 21 (2003) 1323-1356

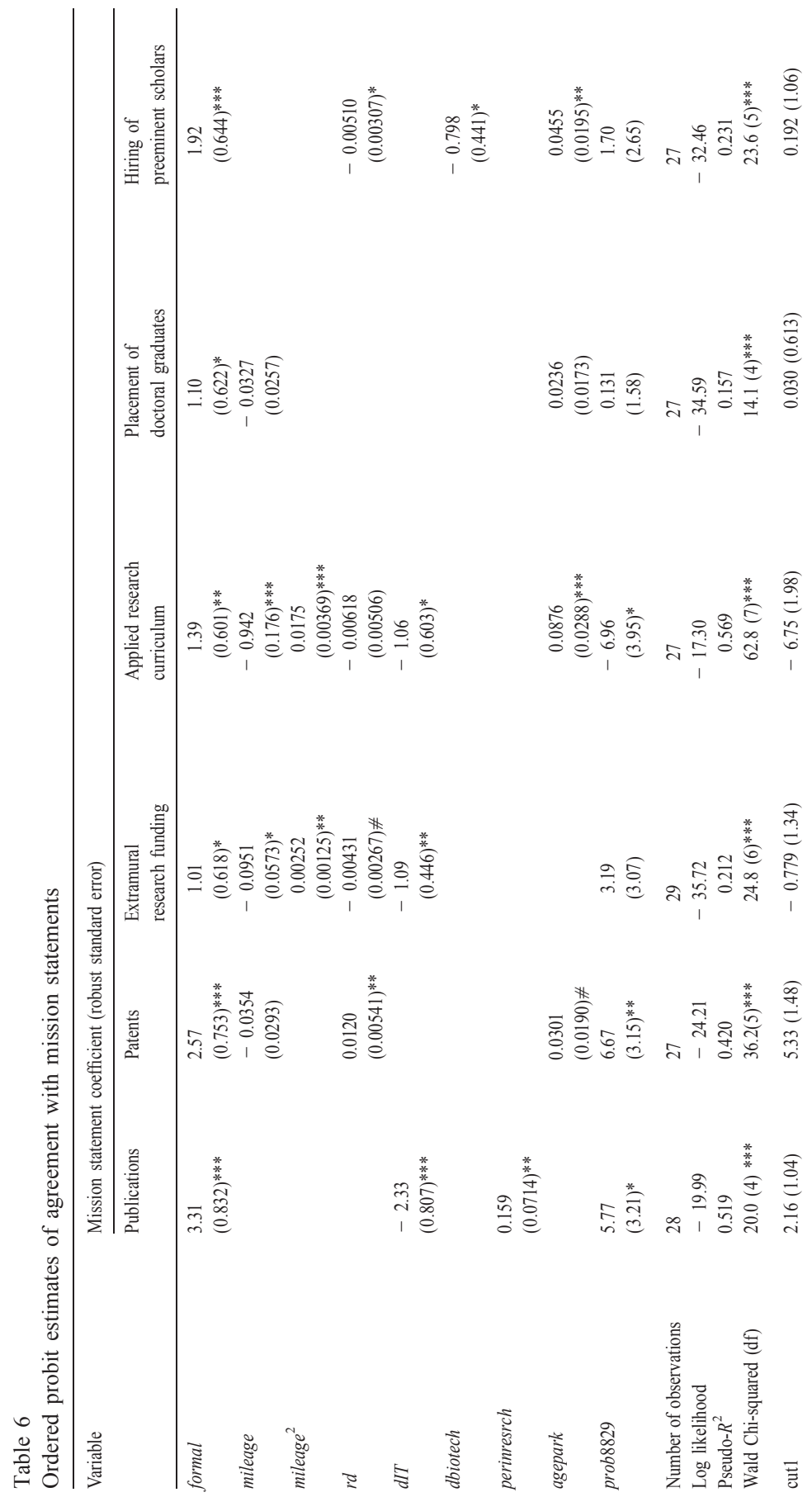




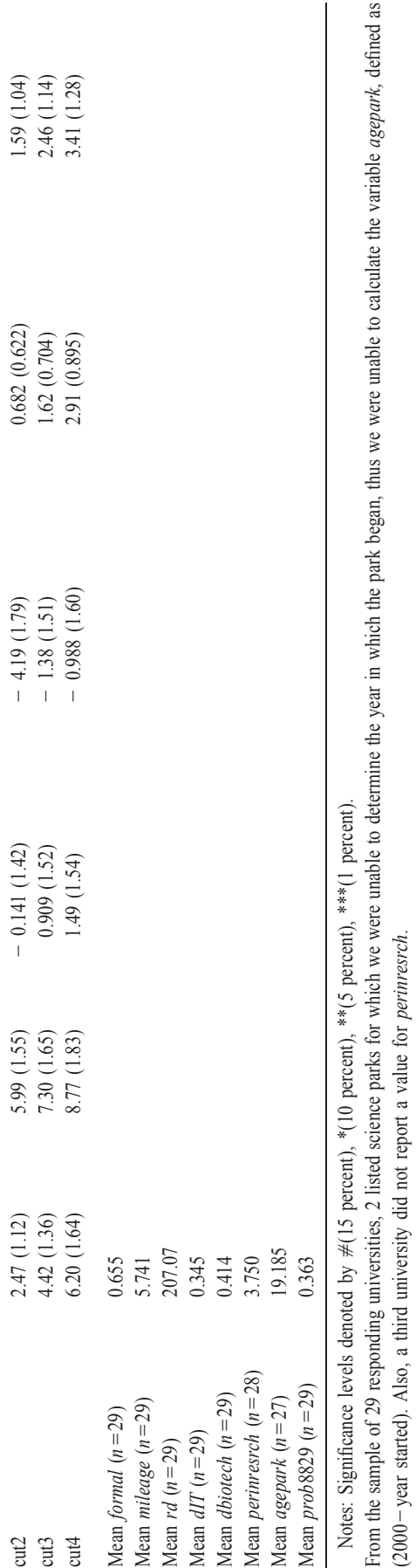


applied research model. It remains an open question whether the effect reflects a substantive effect of unobserved explanatory variables associated with response, or instead is simply the result of correlation of the errors in the model of response and the models of university administrators' perceptions.

\subsection{Interpretation of statistical results for perceptions of science parks' effects on academic missions of universities}

Universities seek external research relationships in an effort to enrich both the knowledge in their research base and the financial value of that knowledge. Herein, we explored how university research relationships with clusters of industrial firms in a science park affect six academic missions. While our sample is relatively small and the information collected from university provosts is qualitative, this study is, to our knowledge, the first to address such impacts in a systematic manner.

The statistical relationships that we found are interesting for a general understanding of science parks and associated knowledge flows. However, the relationships also show how universities that are considering establishing a science park might benchmark their planned activities and structure their relationship with their science park to control the influence of the relationship on academics at the university. Our survey did not apply to 18 of the 47 universities that returned our survey. Five of those 18 universities reported that they are currently planning a science park or are in the process of building one. While we may not see a resurgence of the creation of new science parks as observed in the mid- to late 1980s (see Fig. 1), our survey data and informal discussions with science park directors suggest that the science park phenomenon is again on the rise. Put differently, in terms of our model as illustrated in Fig. 4, a new logistic curve may be taking off from the plateau attained after the first half century of science park growth. As university administrators deal with collaborative research relationships in science parks, our results suggest the following expectations.

First, the organizational nature of the university-park relationship is important. Our measures of a formal versus an informal relationship apparently capture important differences in how universities form a research relationship with their science park. When the relationship is formal, specific impacts will follow including enhanced research output (e.g., publications and patents), increased extramural funding, and improvements in hiring and placement capabilities.

Second, proximity of the science park to the university has an impact on various aspects of the university's academic mission. Proximity, other things held constant, increases success in obtaining extramural funding. Further, other factors held constant, a science park located on or very close to the university campus confers greater employment opportunities for doctoral graduates. But, this nexus 
also has a curricular influence by causing a more applied research curriculum other things being the same.

Third, ceteris paribus, more R\&D-active universities are more likely to report that their interaction with science park organizations positively affects their propensity to patent. They are less likely to report science park effects on their extramural funding activity or on their ability to hire preeminent scholars. The R\&D activity within the university is considered in more detail below.

Fourth, as measured by the percentage of faculty, the intensity with which university faculty are engaged in research with science park organizations appears to have little measurable impact on the effect of science parks on the academic missions of universities except on publications.

Fifth, the influence of university-park research interactions may change over the life of the interaction. Over time, the impact that science parks have on academic missions changes. Initially, that impact may not influence patenting activity or curriculum, but over time it will. Similarly, over time the reputation of the science park will confer a hiring advantage to the university, ceteris paribus. ${ }^{33}$

Reemphasizing the caveats associated with this study, namely that we rely on the provosts' perceptions of effects (rather than time-series data about the effects) and that our sample is small, the results in Table 6 may nevertheless be useful for guiding aspects of university decision making. The results may inform the decision making of universities that have science parks and are trying to understand the full extent of the university-park relationship. Also, the results may inform universities that are contemplating establishing a science park or planning one. We illustrate this with two examples, both focusing on the effect of a university's involvement with a science park on the applied nature of the university's research curriculum. That dimension of curricular focus has gained attention in recent years. As noted previously, Nelson (2001) has warned that as universities take on commercial activities, often in conjunction with industry, their commitment to public science may be endangered. Stephan (2001) as well has noted that there is the potential that technology transfer activities-likely to occur from university/ science park interactions-will divert faculty away from students and curriculum and towards commercial activities such as the quest for extramural research funding. If such funding comes from industrial firms, then it is reasonable to be concerned that commercial influences will spill over to influence the character of the university's research and hence its research curriculum.

\footnotetext{
${ }^{32}$ Nelson (2001) is concerned that commercialization of university research may have a detrimental effect on its 'public science.' Stephan (2001) observes that university/industry research partnerships have a potential to have a detrimental affect on the university's basic research curriculum. This issue is discussed in more detail in Poyago-Theotoky et al. (2002).

${ }^{33} \mathrm{We}$ did investigate the possibility of a nonlinear age of park effect, but that variable never entered at even a marginally significant level.
} 
First, consider a university that has an ongoing relationship with organizations in a science park; consider also the ordered probit results presented in Table 6 for the applied research curriculum mission of the university. Ceteris paribus, as $r d$ increases, there is a decrease in the probability of agreement with the mission statement that the university's research curriculum has become more applied as a result of its involvement with organizations in a science park. The point is that university $\mathrm{R} \& \mathrm{D}$ activity is an instrument that the university can use to control the impact that its involvement with its science park has on its curricular mission. As well, university $\mathrm{R} \& \mathrm{D}$ activity is an instrument useful in predicting, in a benchmarking sense, what impact to expect from its science park involvement. Interpreted slightly differently, the research culture of the university-and we suggest that the 'strength' of that culture may be related to the intensity of the university's R\&D activity - that also confers an academic reputation on the university, offsets outside (e.g., through science park relationships) influences that push the academic curriculum away from basic research toward applied research.

Second, consider a university planning a science park. Again, using the estimated coefficients in Table 6 , ceteris paribus, for a reasonable range around the sample mean, as mileage increases, the probability of agreement with the mission statement that the university's research curriculum has become more applied as a result of its involvement with organizations in a science park decreases. Proximity does matter. When planning an on-campus science park, mileage $=0$, provosts should expect over time a significant applied influence in the research curriculum from that relationship. Ceteris paribus, the probability of such an influence decreases rapidly when the cluster of industrial firms is off campus.

\section{Conclusions}

There is much to be learned about science parks, in general, and their influence on university activity, in particular. This exploratory paper is only a first step in the new learning about science parks and their effects on the academic missions of universities. We have in our paper modeled the appearance of science parks throughout the last half of a century as the diffusion of an innovation-the innovation of the modern science park. With the model, we could describe the hazard rate for the appearance of new science parks through time, and we could observe the initial increase in the rate of new park formations about the time of the Bayh-Dole Act's passage, the enactment of the R\&E tax credit, and the rise in research joint venture activity encouraged through the National Cooperative Research Act, and then the eventual decline in that rate. Understanding the determinants of the rate of formation can inform public policy toward science parks as we enter a new era of growth in the formation of science parks. We have provided initial insights about the forces that stimulate the growth of a science 
park once it has been established. We tentatively identified sources of growth from knowledge, financial, and real estate resources, holding constant the types of technologies associated with the science park and its geographic region and the apparent effect of the technology policies. Further development of the model will be important to inform public policy toward science parks. Finally, we surveyed university administrators to discover their perceptions about the impacts of science parks on their universities' academic missions. Formal association with a science park tends to be perceived by the university administrators as increasing research outputs as measured by publications and patents, as increasing extramural funding, as improving their universities' prospects for hiring preeminent scholars and for placing doctoral graduates. Proximity to a science park improves success in obtaining extramural funding, and proximity improves a university's doctoral graduates' prospects for jobs. However, the applied nature of the university's research curriculum increases with such proximity; R\&D spending at the university reduces that impact.

Future research can extend and develop the findings of this exploratory paper. Regarding the diffusion of the innovation of science parks, the underlying determinants of our model's gamma and lambda can be further developed and explored with data describing the resources available in the geographical environments that host the science parks. For future research about adoptions of the science park concept, samples should include not only established science parks, but as well entrepreneurial groups considering establishment of a park yet never adopting the science park innovation within the sample period. That is, the sample would include entrepreneurial groups that 'survive' throughout the sample period-hence do not 'fail' in the language of the survival time model-and do not adopt the science park innovation. Further, the samples could include parks that were established-adopted the science park concept-but then failed as science parks. Our preliminary work with the growth of science parks once they are established suggests the importance of the knowledge, financial, and real estate resources available to a science park, but future research is needed to develop our exploratory findings.

Our initial look at the perceptions of university administrators is only a beginning in developing understanding about the impact of science parks on the academic missions of universities. The sample size is necessarily small when the unit of observation is the university itself, and a useful extension of our exploratory study could focus on multiple respondents for each university. Multiple respondents could be developed with interviews of faculty members as well as university administrators, and with respondents representing industry participants in the science park. The multiple responses-combined with additional data (including data about the geographic and economic areas in which the parks are located and including qualitative historical data) about the universities and the science parks - will allow future research to develop further the understanding of the interactions between the university and the associated science 
park. ${ }^{34}$ In particular, our findings suggest that the proximity of the science park to the university has no discernable impact on two of the six dimensions of the academic mission. We expect that the reason may simply be the small size of our sample, but future research should explain why, and it should also develop the timing of science park impacts on the academic missions of universities.

Further, in addition to working with the perceptions of those involved with the university/science park interactions, quantitative measures of the interactions' effects should be evaluated in future research. For example, future work could attempt to assess quantitatively a university's success in basic research as a function of the degree of involvement with a science park, measuring success with citation counts or ranking of graduate programs in science and engineering. Additionally, our exploratory study focused on the experience in the United States with its patent law, its mix of public and private universities, and so forth; one expects different experiences in different countries, and future research will develop those differences and thereby increase knowledge about the science park/university interactions.

\section{Acknowledgements}

Earlier versions of parts of this paper were presented at the University of Nottingham's Institute for Enterprise and Innovation/National Academy of Sciences' Board of Science, Technology and Economic Policy Collaborative Conference on "Policies to Promote Entrepreneurship in a Knowledge-Based Economy: Evaluating Best Practices from the U.S. and U.K," September 18-19, 2000; at the Industrial Organization Society's session on "Innovations in Industrial Organization of R\&D and Technology Transfer" at the Allied Social Sciences Association's meetings in New Orleans, January 5, 2001; at the Georgia Institute of Technology Roundtable for Engineering Entrepreneurship Research Conference, March 21-23, 2002; and at two workshops at the University of North Carolina at Greensboro - the National Science Foundation Workshop on Science Park Indicators, November 14, 2002, and the Workshop on the Economics of Intellectual Property at Universities, November 15, 2002. We appreciate comments from the participants at those conferences, especially those from Irwin Feller and Donald Siegel, as well as comments from Richard Arnott regarding the directions

\footnotetext{
${ }^{34}$ The details that distinguish science parks may be crucial to understanding the perceptions that we have documented in our exploratory study. Future research should develop those details. Richard Arnott has suggested (personal correspondence, July 26, 2002) questions such as the following ones. "Do most faculty who have an association with a research park consult or are they part owners of start-up companies? If a professor develops a product in a science park that derives from basic research performed at the university, who has the patent rights? Do the professor's research students at the university routinely get involved in their science park activities?"
} 
for future research. We also appreciate the generous funding provided by the National Science Foundation to conduct this study.

\section{Appendix A}

In this Appendix, we discuss alternative econometric approaches to the question of how a university's relationship with a science park affects the academic missions of the university. One alternative to exploring inter-university differences in perceived effects of a science park on academic missions would have been to collect quantitative data on aspects of university activity (e.g., publications, patents, extramural funds, curriculum, student placements, and hiring) and estimate for each university a time series model, controlling for the date that the university began its relationship with the science park. Such a model as

$$
\text { academic activity }_{t=0 \text { to } t=n}=f \text { (science park interaction }_{t=0 \text { to } t=n} \text { ) }
$$

has the benefit of relying on objective data to quantify academic activity on the left. However, the error in the equation may be correlated (causing biases in the estimates of the model's coefficients) with the errors in the observations of the independent variables - errors that may be severe because there is no meaningful way to date when a university began to have relationship with a park. Parks evolve over time from a concept to a development project to an infrastructure housing research partners. Research Triangle Park is a case in point. Faculty from Duke University, University of North Carolina, and North Carolina State University (then State College) were involved with the Park before the Park became a park. That is, faculty were integrally involved in research relationships with companies as far back as the late 1950 s, although the first tenant did not commit to the Park until 1965 and began research operations more than a year later. In other cases, there have been long standing relationships between the university and the park, but the park has yet to move from a land development corporation to one with research tenants. Or, we could have created a matched sample of universities with and without a science park relationship and compared the performance of each group of universities. Such a model as

$$
\begin{aligned}
& \text { academic activity university A vs. university B } \\
& =f(\text { science park interaction university A vs. university B })
\end{aligned}
$$

also has the advantage of objective data on the left, but there is not a meaningful (as opposed to systematic) way to create a matched sample of universities that do not have a science park relationship. Again, we expect correlation between the error in equation and the errors in the explanatory variables. There are two main reasons for those errors. One, the relationship between a university and park is an 
evolving one, as just discussed, and, even controlling for age of park, the sample of universities with park relationships would still have a degree of heterogeneity that could not be matched in the sample of universities without park relationships. And two, we would have had no way to hold constant in such an experiment other industry influences on the university that occurred as a result of research or other interactions outside of the geographic park setting. As compared with our approach, the alternative approaches represented by Eqs. (A.1) and (A.2) have some advantages despite the potentially bias-inducing errors in variables difficulties we have identified. Just as clearly, however, our approach has its own advantages, and the perceptions of the universities' provosts about the effects of the science park affiliations on the universities' missions are important in themselves. Although the dependent variables in the versions of Eq. (12) that were estimated clearly reflect perceptions, we are convinced, as a result of our pretests, that provosts reported well-informed perceptions. And, given that the dependent variable reflects perceptions, ordered probit is the appropriate econometric technique. The alternative models noted above would also have contained judgmental information, but would have done so in a manner that would be likely to create an important errors in variables problem. Although there are econometric approaches to dealing with the errors in variables problem, the errors introduced in the two alternative models would be central to the time series investigation and especially intractable.

\section{References}

Adams, J.D., 2002. Comparative localization of academic and industrial spillovers. Journal of Economic Geography 2, 253-278.

Adams, J.D., Jaffe, A.B., 1996. Bounding the effects of R\&D: An investigation using matched establishment-firm data. Rand Journal of Economics 94, 700-721.

Association of University Related Research Parks (AURRP), 1997, Worldwide Research \& Science Park Directory 1998. BPI Communications.

Audretsch, D.B., Bozeman, B., Combs, K.L., Feldman, M.P., Link, A.N., Siegel, D.S., Stephan, P.E., Tassey, G., Wessner, C., 2002. The economics of science and technology. Journal of Technology Transfer 27, 155-203.

Bakouros, Y.L., Mardas, D.C., Varsakelis, N.C., 2002. Science park, a high tech fantasy?: An analysis of the science parks of Greece. Technovation 22, 123-128.

Carnegie Foundation for the Advancement of Teaching, 2001. The Carnegie Classification of Institutions of Higher Education, 2000 Edition. Carnegie Foundation, Menlo Park, California.

Castells, M., Hall, P., 1994. Technopoles of the World. Routledge, London.

Chordà, I.M., 1996. Towards the maturity state: An insight into the performance of French technopoles. Technovation 16, 143-152.

Cohen, W.M., Levinthal, D.A., 1989. Innovation and learning: The two faces of R\&D. Economic Journal 99, 569-596.

Cohen, W.M., Florida, R., Randazzese, L., Walsh, J., 1997. Industry and the academy: Uneasy partners in the cause of technological advance. In: Noll, R. (Ed.), Challenge to the University. Brookings Institution Press, Washington, D.C. 
Danilov, V.J., 1971. The research park shake-out. Industrial Research 13, 1-4.

Davies, S., 1979. The Diffusion of Process Innovations. Cambridge University Press, Cambridge.

Dixon, R.J., 1980. Hybrid corn revisited. Econometrica 48, 145-146.

Feldman, M., 1999. The new economics of innovation, spillovers and agglomeration: A review of empirical studies. Economics of Innovation and New Technology 8, 5-25.

Feldman, M., Lichtenberg, F., 2002. Innovation, imitation and distance in the pharmaceutical industry. Mimeograph, Johns Hopkins University.

Geroski, P.A., 2000. Models of technology diffusion. Research Policy 29, 603-625.

Gibb, M.J., 1985. Science Parks and Innovation Centres: Their Economic and Social Impact. Elsevier, Amsterdam.

Grayson, L., 1993. Science Parks: An Experiment in High Technology Transfer. The British Library Board, London.

Guy, I., 1996a. A look at Aston Science Park. Technovation 16, 217-218.

Guy, I., 1996b. New ventures on an ancient campus. Technovation 16, 269-270.

Hall, B.H., Link, A.N., Scott, J.T., 2000. Universities as research partners. NBER Working Paper 7643.

Hall, B.H., Link, A.N., Scott, J.T., 2003. Universities as research partners. Review of Economics and Statistics 85, 485-491.

Link, A.N., 1995. A Generosity of Spirit: The Early History of the Research Triangle Park. University of North Carolina Press for the Research Triangle Park Foundation, Research Triangle Park.

Link, A.N., 1996. Research joint ventures: Patterns from Federal Register filings. Review of Industrial Organization 11, 617-628.

Link, A.N., 2002. From Seed To Harvest: The History of the Growth of the Research Triangle Park. University of North Carolina Press for the Research Triangle Park Foundation, Research Triangle Park.

Link, A.N., Scott, J.T., 2003. The growth of Research Triangle Park. Small Business Economics 20, $167-175$.

Löfsten, H., Lindelöf, P., 2002. Science parks and the growth of new technology-based firmsAcademic-industry links, innovation and markets. Research Policy 31, 859-876.

Luger, M.I., Goldstein, H.A., 1991. Technology in the Garden. University of North Carolina Press, Chapel Hill.

Maddala, G.S., 1983. Limited Dependent and Qualitative Variables in Econometrics. Cambridge University Press, Cambridge.

Massey, D., Qunitas, P., Wield, D., 1992. High-tech Fantasies: Science Parks in Society, Science and Space. Routledge, London.

Monck, C.S.P., Porter, R.B., Quintas, P., Storey, D.J., Wynartczyk, P., 1988. Science Parks and the Growth of High Technology Firms. Croom Helm, London.

Morgan, R.P., 1998. University research contributions to industry: The faculty view. In: Blair, P., Frosch, R. (Eds.), Trends in Industrial Innovation: Industry Perspectives \& Policy Implications. Sigma Xi, The Scientific Research Society, Research Triangle Park, pp. 163-170.

Mowery, D.C., Teece, D.J., 1996. Strategic alliances and industrial research. In: Rosenbloom, R., Spenser, W. (Eds.), Engines of Innovation: U.S. Industrial Research at the End of an Era. Harvard Business School, Boston, pp. 111-129.

National Science Board, 2000. Science \& Engineering Indicators-2000. National Science Foundation, Arlington, Virginia.

Nelson, R.R., 2001. Observations on the post-Bayh-Dole rise of patenting at American universities. Journal of Technology Transfer 26, 13-19.

Phillimore, J., 1999. Beyond the linear view of innovation in science park evaluation: An analysis of Western Australian Technology Park. Technovation 19, 673-680.

Poyago-Theotoky, J., Beath, J., Siegel, D.S., 2002. Universities and fundamental research: Reflections on the growth of university-industry partnerships. Oxford Review of Economic Policy 18, 10-21.

Price, D.J. de Solla, 1963. Little Science, Big Science. Columbia University Press, New York.

Saxenian, A.L., 1994. Regional Advantage. Harvard University Press, Cambridge. 
Siegel, D.S., Thursby, J.G., Thursby, M.C., Ziedonis, A.A., 2001. In: Symposium On Organizational Issues in University-Industry Technology Transfer. Journal of Technology Transfer, Vol. 1-3.

Siegel, D.S., Westhead, P., Wright, M., 2003. Science parks and the performance of new technologybased firms: A review of recent U.K. evidence and an agenda for future research. Small Business Economics 20, 177-184.

StataCorp, 2001. Stata Statistical Software: Release 7.0, Vol. 3. Stata Corporation, College Station, Texas.

Stephan, P.E., 2001. Educational implications of university-industry technology transfer. Journal of Technology Transfer 26, 199-205.

Sternberg, R., 1990. The impact of innovation centres on small technology-based firms: The example of the Federal Republic of Germany. Small Business Economics 2, 105-118.

United Kingdom Science Park Association (UKSPA), 1985. Science Park Directory. UKSPA, Sutton Coldfield.

U.S. General Accounting Office, 1983. The Federal Role in Fostering University-Industry Cooperation. GAO, Washington, D.C.

Vedovello, C., 1997. Science parks and university-industry interaction: Geographical proximity between the agents as a driving force. Technovation 17, 491-502.

Wallsten, S., 2001. An empirical test of geographic knowledge spillovers using geographic information systems and firm-level data. Regional Science and Urban Economics 31, 571-599.

Wessner, C.W. (Ed.), 1999. A Review of the Sandia Science and Technology Park Initiative. National Research Council, Washington, D.C.

Wessner, C.W. (Ed.), 2001. A Review of the New Initiatives at the NASA Ames Research Center: Summary of A Workshop. National Research Council, Washington, D.C.

Westhead, P., 1997. R\&D 'inputs' and 'outputs' of technology-based firms located on and off science parks. R\&D Management 27, 45-62.

Westhead, P., Batstone, S., 1998. Independent technology-based firms: The perceived benefits of a science park location. Urban Studies 35, 2197-2219.

Westhead, P., Cowling, M., 1995. Employment change in independent owner-managed high-technology firms in Great Britain. Small Business Economics 7, 111-140.

Westhead, P., Storey, D.J., 1994. An Assessment of Firms Located On and Off Science Parks in the United Kingdom. HMSO, London.

Westhead, P., Storey, D.J., Cowling, M., 1995. An exploratory analysis of the factors associated with the survival of independent high-technology firms in Great Britain. In: Chittenden, F., Robertson, M., Marshall, I. (Eds.), Small Firms: Partnerships For Growth. Paul Chapman, London, pp. 63-99. 